\title{
ECOLOGICAL RISK ASSESSMENTS OF HEAVY METALS IN SURFACE SEDIMENTS COLLECTED FROM HAQAL COASTAL WATERS (TABUK REGION), SAUDI ARABIA
}

AL-ShAMI, S. A. $.^{*}-$ YAP, C. K. ${ }^{2}-$ WONG, K. W. ${ }^{2}-$ AL-QAHTANI, S. M. ${ }^{1}-$ ALSABIH, L. $^{1}-$ AL-ZAQRI, N. ${ }^{3}$

${ }^{1}$ Biology Department, University College of Taymma, University of Tabuk Taymma, P. O. Box 741, Tabuk, Saudi Arabia

${ }^{2}$ Department of Biology, Faculty of Science, Universiti Putra Malaysia 43400 UPM, Serdang, Selangor, Malaysia

${ }^{3}$ Department of Chemistry, College of Science, King Saud University Riyadh 11451, Saudi Arabia

*Corresponding author

e-mail:salshami@ut.edu.sa, alshami200@gmail.com; phone:+966-55-923-0853; fax: +966-14-425-1127

(Received $6^{\text {th }}$ Dec 2018; accepted $28^{\text {th }}$ Jan 2019)

\begin{abstract}
Haqal is a small city located in north-western part of Arabian Peninsula. The anthropogenic activities in this region are evident. This region is targeted for future development by Saudi government. In this study, the surface sediment of Haqal coastal waters were analysed for heavy metals $(\mathrm{Cd}, \mathrm{Cu}, \mathrm{Fe}$, $\mathrm{Ni}, \mathrm{Pb}$, and $\mathrm{Zn}$ ). The total concentration ( $\mathrm{mg} / \mathrm{kg}$ dry weight) ranged from $0.012-0.186$ for $\mathrm{Cd}, 0.582-1.13$ for $\mathrm{Cu}, 0.51-2.18$ for $\mathrm{Ni}, 0.68-2.64$ for $\mathrm{Pb}, 1.97-4.52$ for $\mathrm{Zn}$ while for $\mathrm{Fe}$, it ranges from 0.155 to $0.254 \%$. Based on ecological risk assessment results, the values of PERI were categorised as 'low ecological risk', thus all sampling sites were unpolluted with heavy metals. Despite that, this monitoring study had a positive result for non-heavy metal pollution, future mitigation of the heavy metal pollution in coastal areas of Tabuk should be given priority by the authorities. The present study can be considered as the first effort to monitor the pollution of heavy metals in Haqal. This provides baseline information for future ecotoxicological studies which can involve application of bioindicators to assess the quality of the marine environment in this region.
\end{abstract}

Keywords: The Red Sea, marine environment, Arabian Peninsula, pollution

\section{Introduction}

Sediment is an important sink where pollutants are accumulated from the water body, and a secondary pollution source which might impact the surrounding aquatic ecosystem (Birch and Taylor, 2002; Wang et al., 2011; Hahladakis et al., 2016; Kumwimba et al., 2017; Wong et al., 2017). Thus, determining the ecological risks to aquatic ecosystems posed by heavy metal toxicity is crucial to be determined (Kumwimba et al., 2017; Wong et al., 2017). In this study, two approaches were deployed to assess ecological risks for heavy metals in sediments, i.e. 1) sediment total metal concentrations, and 2) metal GFs in sediment. The sub-approaches that are based on total metal concentrations are i) comparisons with sediment quality guidelines (SQGs), ii) geochemical pollution indexes (Igeo), and enrichment factor (EF), iii) contamination factor (Cf), potential risk of individual metal (Er) and potential ecological risk index (PERI), proposed by Hakanson (1980). These SQGs are developed for marine and estuarine ecosystems (Long et al., 1995) via (a) the effect range low 
(ERL)/effect range median (ERM)/interim sediment quality value-low (ISQV-low) and (b) the threshold effect level (TEL)/probable effect level (PEL)/interim sediment quality value-high (ISQV-high) values.

Originating from Long and Morgan (1990), the SQG is an informal tool to evaluate sediment chemical data in relation to possible adverse effects on aquatic biota. The SQGs were proposed to be used as benchmark for evaluating sediment chemistry information to identify situations that are potentially harmful to aquatic organisms associated with bad sediments; as well as the benchmark to help set targets for sediment quality for the broader management strategy of long term aquatic ecosystem health sustainability management (CCME, 2002).

Among the basics of SQGs, SQGs based on ERL and ERM are used extensively in assessment of the pollutants' impact on environment. It has been tested against a large dataset gained in US EPA and US NOAA (National Oceanic and Atmospheric Administration, US). These datasets consisted of synchronized measurements of chemical and toxicological variables (O'Connor, 2004). However, O'Connor (2004) has made a clarification that SQG's ERL is not a threshold chemical toxicity in sediment and there is no basis for the assumption of pollutant concentration above ERL increase the probability of toxicity. However, there are still multiple recent heavy metal risk assessment studies that are employing ERL-ERM-based SQG at their assessment (Long and Morgan, 1990; Yap, 2010; Yap et al., 2002; Amin et al., 2009; Garcia et al., 2011; Ali et al., 2015). Therefore, the ERL and ERM approach of risk assessments are still viable approaches of heavy metal risk assessment and will still be used to evaluate the heavy metal risk in this study. In this study, the heavy metal levels in sediments were compared SQGs with multiple approaches (ERL, ERM, TEL and PEL) to assess and deduce the possible environmental impact of the sediment's heavy metals level. Hakanson (1980) has proposed a series of indexes as diagnostic tools for pollution control purposes, i.e. the contamination factor $(\mathrm{Cf})$, risk index of individual metal (Er) and Total Risk Index (RI), and degree of contamination.

Ecological risk assessment (ERA) using above-mentioned approaches have been widely used in ERA-based studies. These studies reported have wide geographical distribution. In Asia region, there are such reports from Malaysia (Yap et al., 2002 and Yap, 2010), Khuzestan coastal waters, Iran (Madiseh et al., 2009), Northern Bohai and Yellow Seas, China (Luo et al., 2010), Dongjiang Harbor, China (Guo et al., 2010), Yangtze Estuary, China (Zhao et al., 2012), Lake Cildır, Turkey (Kukrer et al., 2014), Ulsan Bay, Korea (Ra et al., 2014), and mangrove sediments of Peninsular Malaysia (Cheng and Yap, 2015).

Tabuk coastal areas including Haqal city supported high floral and faunal diversity. On the other hand, the environment of the coastal areas of Haqal is threatened by several human activities which may increase the pollution burden to the area. Studies on monitoring of heavy metals in these areas are scarce. On the other hand, this area has a promising future as it is targeted for future development with the country development plan. Thus, this study can be considered as pioneer in the assessment of heavy metal contamination of the coastal environment of Haqal. The present study aims to estimate the ecological risk assessments in the surface sediment collected from Haqal coastal waters based on 1) SQGs, 2) two geochemical pollution indexes, and 3) PERI. 


\section{Materials and methods}

\section{Study site}

Haqal is a small city belongs to Tabuk region and is located in the north-western part of Arabian Peninsula. It is located within geographical coordinates of $29^{\circ} 17^{\prime} 39^{\prime \prime}$ North, $34^{\circ} 57^{\prime}$ " " East. It is situated in the northwest of Saudi Arabia near the head of the Gulf of Aqaba adjacent to Aqaba across the Jordanian border (lies about $5 \mathrm{~km}$ from Jordanian border). This is coastal area is not a port used for the Red Sea shipping. However, coasts of the region are scenic. The climate of this city is arid with annual rainfall of less than $50 \mathrm{~mm}$. The rainy season is in the winter and the annual mean temperature is $24^{\circ} \mathrm{C}$. This region is targeted for future development under the NEOM project. Therefore, it is expected that this region will witnessed huge infrastructure development and the environmental assessment is a necessary tool at this stage.

\section{Collection of sediment samples}

The surface sediments ( $3-5 \mathrm{~cm}$ from surface sediment) in 15 sites of Haqal coastal areas were collected on early summer of 2018 (Fig. 1). The plastic spoon was used to collect the top-sediment to minimize the metal contamination. Sufficient amount of the sediment was collected from each site. The collected sediment samples were transferred into an acid-washed polyethylene bag and brought back to laboratory for temporary storage and analysis. The samples taken back to laboratory were frozen $\left(-20{ }^{\circ} \mathrm{C}\right)$ in a freezer prior to analysis.

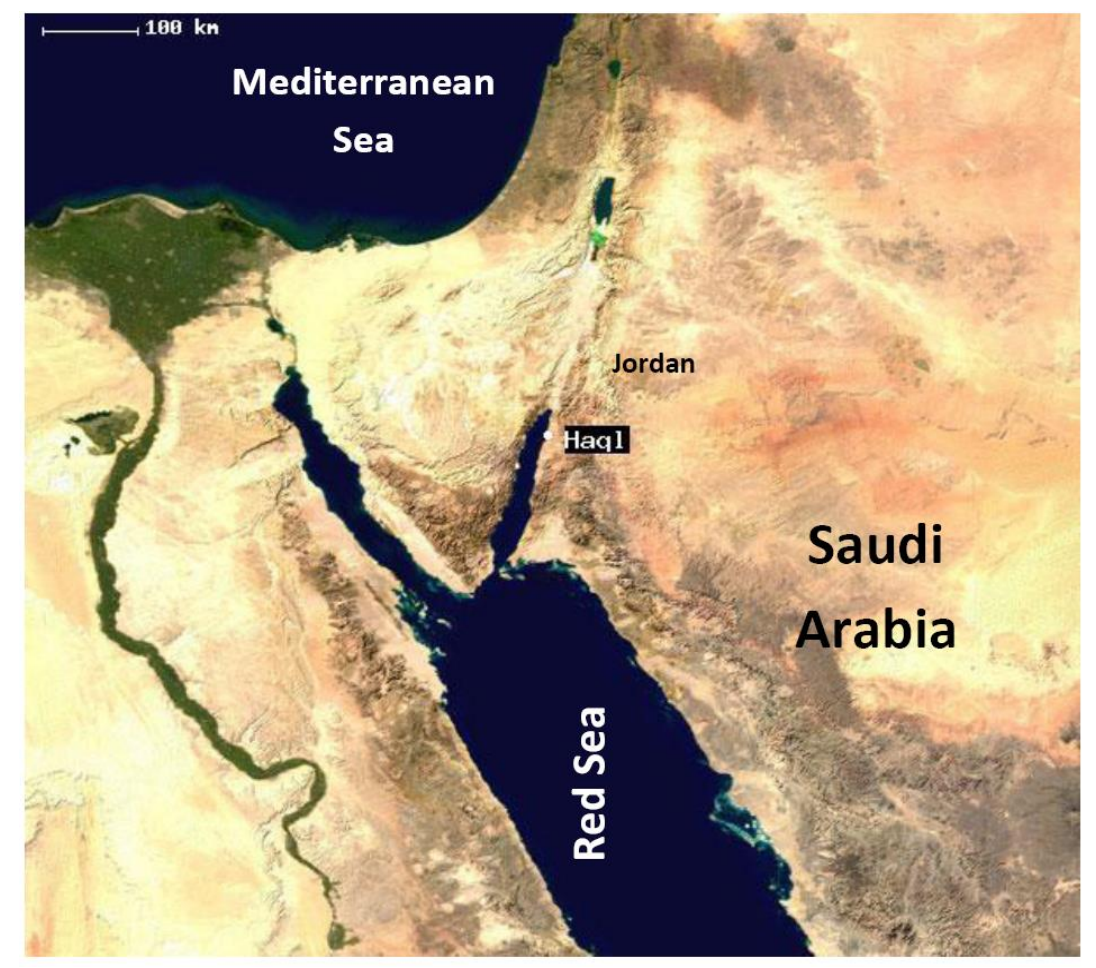

Figure 1. Map showing sampling area in Haqal coastal waters in Tabuk, Saudi Arabia

Before the analysis, sediment samples were oven-dried at $60{ }^{\circ} \mathrm{C}$ for at least $16 \mathrm{~h}$ until constant dry weights were achieved. Then the dried sediment particles were sieved 
through a $0.50 \mathrm{~mm}$ stainless steel sieve. During the sieving process, the samples were also shaken vigorously to produce homogeneity. Only sediment particles with size below $63 \mu \mathrm{m}$ in diameter are considered for metal analysis.

The analyses of total $\mathrm{Cd}, \mathrm{Cu}, \mathrm{Fe}, \mathrm{Ni}, \mathrm{Pb}$ and $\mathrm{Zn}$ concentrations in sediment samples were done according to direct aqua-regia method. After sieving, about one gram of each dried sample (Particle size $<63 \mu \mathrm{m}$ ) was weighed and digested in a aqua-regia solution, which is a combination (ratio 4:1) of concentrated $\mathrm{HNO}_{3}$ (AnalaR grade, BDH 69\%) and $\mathrm{HClO}_{4}$ (AnalaR grade, $\mathrm{BDH} 60 \%$ ). The digestion was first conducted at low temperature $\left(40{ }^{\circ} \mathrm{C}\right)$ for $1 \mathrm{~h}$ and then the temperature was elevated to $140{ }^{\circ} \mathrm{C}$ for a minimum $3 \mathrm{~h}$ until the samples have been fully digested. The resulting solutions of the digestion were than diluted to a fixed volume of $40 \mathrm{ml}$ using double distilled water. The sample was then filtered filter paper (Whatman no. 1, pore size $11 \mu \mathrm{m}$ ) and the filtrates were stored until metal determination. Flame-Atomic Absorption Spectroscopy (FAAS; Perkin Elmer Model AAnalyst 800) was used to determine the concentration of $\mathrm{Cd}, \mathrm{Cu}$, $\mathrm{Fe}, \mathrm{Ni}, \mathrm{Pb}$ and $\mathrm{Zn}$. The resulting data were expressed as $\mathrm{mg} / \mathrm{kg}$ of samples' dry weight (dw).

To ensure the accuracy and credibility of the result, some pre-caution steps have been done. During metal analysis, a quality control sample was routinely analysed to ensure the accuracy of the analysis. As the result, the metal recovery of the quality control samples was acceptable at $90-110 \%$. All glassware and equipment used during sample processing and metal analysis were soaked in $10 \% \mathrm{HNO}_{3}$ to wash away the possible metal contaminant. Certified Reference Materials (CRM) for Soil (International Atomic Energy Agency, Soil-5, Vienna, Austria) was used to assure the quality of direct aqua-regia method. The CRM was treated exactly the same as the other samples. The result of metal analysis was compared to the certified reference value of the respective metals. The recovery of the CRMs was found to be satisfactory.

\section{Data treatment}

\section{Geoaccumulation index (Igeo $)$}

The values of Igeo were calculated according to Muller's (1969) formula (Eq. 1):

$$
I_{g \oplus 0}=\log _{2} \frac{c_{n}}{1.5 \times B_{n}}
$$

where $C_{n}$ is the sediment heavy metal concentrations and $B_{n}$ is the "preindustrial reference values" (PRV; unit $=\mathrm{mg} / \mathrm{kg}$ dw; Hakanson, 1980) which act as geochemical background values for each metal. The PRV for $\mathrm{Cd}, \mathrm{Cu} \mathrm{Pb}$ and $\mathrm{Zn}$ was 1.0, 50, 70 and 175, respectively (Hakanson, 1980). Owing to the absence of the PRV of Fe and Ni was taken from "upper continental crust" from Wedepohl (1995) and Rudnick and Gao (2003), in which the values were $3.09 \%$ and $47.0 \mathrm{mg} / \mathrm{kg} \mathrm{dw}$, respectively (Table 2).

To minimize the possible variation in background metal concentrations which might be contributed by lithogenic variations, a factor of 1.5 was introduced into the formula (Al-Haidarey et al., 2010; Hasan et al., 2013). It permits the content fluctuation of the metals in sediment and also some negligible anthropogenic influences (Loska et al., 1997; Hurley et al., 2017). Muller (1969) has classified the resulting Igeo values into six classes according to the extent of the metal geoaccumulation. 


\section{Enrichment factor $(E F)$}

The EF in this study was determined using a formula defined by Buat-Menard and Chesselt (1979), with Fe as a normaliser (Eq. 2):

$$
E F=\frac{\left(\frac{C_{n}}{C_{F e}}\right)_{\text {sample }}}{\left(\frac{C_{n}}{C_{F e}}\right)_{\text {crust }}}
$$

where $\left(\mathrm{C}_{\mathrm{n}} / \mathrm{C}_{\mathrm{Fe}}\right)$ sample is the metal to $\mathrm{Fe}$ ratio in the sediments; $\left(\mathrm{C}_{\mathrm{n}} / \mathrm{C}_{\mathrm{Fe}}\right)$ crust is the metal to $\mathrm{Fe}$ ratio in the earth crust which considered as pre-industrial unpolluted metal value of a sediment.

The normalisation using Fe are necessary to correct for differences in sediment grain size and mineralogy (Schiff and Weisberg, 1999). The use Fe as normaliser was made based on the fact that $\mathrm{Fe}$ is a major sorbent phase for trace metals and is a quasiconservative tracer of the natural metal-bearing phases in fluvial and coastal sediments (Schiff and Weisberg, 1999; Hurley et al., 2017). According to Hasan et al. (2013), natural resources (98\%) vastly dominated the input of Fe. In this expression, the normaliser (reference element) is assumed to have little variability of occurrence, and is present in trace concentration in the examined environment (Loska et al., 1997). The degrees of EF are categorised by Taylor (1964) and Birth (2003).

\section{Ecological risk assessments}

The contamination factor $\left(\mathrm{C}_{\mathrm{f}}\right)$ was calculated to describe the contamination status of metals in the industrial drainages studied (Hakanson, 1980). $\mathrm{C}_{\mathrm{f}}$ was calculated as Equation 3:

$$
C_{f}=\frac{c_{\text {sed }}}{c_{\text {ref }}}
$$

where $C_{f}$ is the contamination factor; $C_{s e d}$ is the mean metal concentration in the sediment; $\mathrm{C}_{\text {ref }}$ is the PRV of metals in the sediments. Hakanson (1980) has classified the $\mathrm{C}_{\mathrm{f}}$ values into 4 categories.

According to Hakanson (1980), the potential risk for individual metal $\left(\mathrm{E}_{\mathrm{r}}\right)$ can be calculated using Equation 4:

$$
E_{r}=T R \times C_{f}
$$

where TR is the toxic-response factor for a metal (Table 2) Due to the fact that the absence of TR value for $\mathrm{Fe}$, the $\mathrm{E}_{\mathrm{r}}$ for $\mathrm{Fe}$ was not calculated. $\mathrm{C}_{\mathrm{f}}$ is the contamination factor for the same substance. The $\mathrm{E}_{\mathrm{r}}$ for each metals were defined in accordance of Hakanson's (1980) standard.

The total risk index (RI) or potential ecological risk index (PERI) was calculated as Equation 5:

$$
R I=\sum_{i=1}^{m} E_{r}=\sum_{i=1}^{m}\left(T R \times C_{f}\right)
$$


where $E_{r}$ is the risk index of individual metal, TR is the toxic-response factor and $C_{f}$ is the contamination factor. The PERI can be described according to categories suggested by Hakanson (1980).

The classification of SQGs along with its effects and comparison results are presented in Table 2. It is important to determine whether the total concentrations of heavy metals in sediments found pose a threat to aquatic life. In the present study, the sediment risk of each metal investigated is assessed by three sets of SQGs namely (1) Effects Range Low (ERL) and Effects Range Medium (ERM) by Long et al. (1995), (2) lowest effect level (LEL) and severe effect level (SEL) by NYSDEC (1999), and (3) threshold effects level (TEL) and probable effects level (PEL) by MacDonald et al. (1996) and MacDonald (2003). These three sets of numerical SQGs were directly applied (without normalization) to assess possible risk arises from the heavy metal contamination in sediments of the study area.

\section{Results and discussion}

The concentrations ( $\mathrm{mg} / \mathrm{kg}$ dry weight; except for Fe in \%) of surface sediments collected from Haqal coastal waters are shown in Table 1. The surface sediment of Tabuk coastal waters from Saudi Arabia were analysed for $\mathrm{Cd}, \mathrm{Cu}, \mathrm{Fe}, \mathrm{Ni}, \mathrm{Pb}$, and $\mathrm{Zn}$. The metal concentrations $(\mathrm{mg} / \mathrm{kg}$ dry weight) ranges for total concentration are 0.012 0.186 for $\mathrm{Cd}, 0.582-1.13$ for $\mathrm{Cu}, 0.51-2.18$ for $\mathrm{Ni}, 0.68-2.64$ for $\mathrm{Pb}, 1.97-4.52$ for $\mathrm{Zn}$ while for $\mathrm{Fe}$, it ranges from $0.155-0.254 \%$. These values of heavy metals are remarkably lower compared to those reported in Jeddah coastal surface by Badr et al. (2009).

Table 1. Concentrations ( $\mathrm{mg} / \mathrm{kg}$ dry weight; except for Fe in \%) of heavy metals of surface sediments collected from Haqal coastal waters (Tabuk, Saudi Arabia)

\begin{tabular}{c|c|c|c|c|c|c}
\hline Location & $\mathbf{N i}$ & $\mathbf{P b}$ & $\mathbf{C u}$ & $\mathbf{Z n}$ & $\mathbf{C d}$ & $\mathbf{F e} \%$ \\
\hline $\mathbf{1}$ & 0.589 & 1.996 & 0.602 & 4.504 & 0.081 & 0.196 \\
$\mathbf{2}$ & 0.506 & 1.738 & 0.873 & 2.699 & 0.012 & 0.216 \\
$\mathbf{3}$ & 2.179 & 1.404 & 0.582 & 2.172 & 0.024 & 0.174 \\
$\mathbf{4}$ & 1.668 & 1.330 & 0.641 & 1.967 & 0.032 & 0.220 \\
$\mathbf{5}$ & 0.971 & 1.478 & 0.885 & 2.336 & 0.090 & 0.168 \\
$\mathbf{6}$ & 1.042 & 1.508 & 0.691 & 3.955 & 0.138 & 0.176 \\
$\mathbf{7}$ & 1.569 & 1.502 & 0.826 & 1.979 & 0.064 & 0.178 \\
$\mathbf{8}$ & 2.083 & 2.162 & 0.802 & 2.897 & 0.031 & 0.205 \\
$\mathbf{9}$ & 1.966 & 2.643 & 1.076 & 3.398 & 0.071 & 0.178 \\
$\mathbf{1 0}$ & 1.747 & 1.727 & 0.898 & 2.006 & 0.125 & 0.186 \\
$\mathbf{1 1}$ & 1.744 & 1.443 & 0.955 & 3.294 & 0.044 & 0.206 \\
$\mathbf{1 2}$ & 0.704 & 1.428 & 0.822 & 2.407 & 0.118 & 0.213 \\
$\mathbf{1 3}$ & 0.863 & 1.206 & 0.988 & 2.528 & 0.186 & 0.254 \\
$\mathbf{1 4}$ & 0.854 & 0.675 & 1.094 & 4.522 & 0.124 & 0.172 \\
$\mathbf{1 5}$ & 1.306 & 1.329 & 1.130 & 3.364 & 0.167 & 0.155 \\
\hline
\end{tabular}

All the values of metals are below ERL, indicating that adverse effects on aquatic biota should rarely occur. There should be no toxicological effects of $\mathrm{Cd}, \mathrm{Cu}, \mathrm{Ni}, \mathrm{Pb}$ 
and $\mathrm{Zn}$ in the present study area and that may not occasionally be associated with adverse biological effects.

When compared to the LEL-SEL SQGs, among the metals, $\mathrm{Cd}, \mathrm{Cu}, \mathrm{Ni}, \mathrm{Pb}$ and $\mathrm{Zn}$ concentrations are also below LEL in all sites. According to Thompson et al. (2005), the LEL represents the contaminant concentration below the harmful effects on benthic invertebrates. However, by comparison to the TEL-PEL SQGs, $100 \%$ of the concentrations of $\mathrm{Cd}, \mathrm{Cu}, \mathrm{Pb}$ and $\mathrm{Zn}$ in all the samples are below TEL. It is interpreted that TEL as the concentrations, below which adverse biological effects rarely occurs. Hence, it is considered to provide a high level of protection for aquatic organisms. This requires a lower level of protection for aquatic organisms.

In comparison to reference values (RVs) (Table 2), all the metals levels of all sites are below the levels of pre-industrial reference (PIR) level (Hakanson, 1980), and the upper continental crust (UCC) values proposed by Taylor and McLennan (1995), Wedepohl (1995) and Rudnick and Gao (2003).

Table 2. Comparisons between total heavy metal concentrations (mean, $\mu \mathrm{g} / \mathrm{g} d w$; except for $\mathrm{Fe}$ in \%) with those cited from sediment quality guidelines (SQGs) and reference values $(R V s)$. The values of toxic-response factors, employed in this study are also presented

\begin{tabular}{|c|c|c|c|c|c|c|c|}
\hline Site no. & Cd & $\mathbf{C u}$ & $\mathrm{Fe}(\%)$ & $\mathbf{N i}$ & $\mathbf{P b}$ & $\mathbf{Z n}$ & References \\
\hline Haqal coastal sediment & $\begin{array}{c}0.012- \\
0.186 \\
\end{array}$ & $\begin{array}{c}0.582- \\
1.13\end{array}$ & $\begin{array}{c}0.155- \\
0.254\end{array}$ & $\begin{array}{l}0.51- \\
2.18\end{array}$ & $\begin{array}{l}0.68- \\
2.64\end{array}$ & $\begin{array}{l}1.97- \\
4.52\end{array}$ & This study \\
\hline Jeddah (Saudi Arabia) & $\begin{array}{l}3.08- \\
3.51 \\
\end{array}$ & $\begin{array}{l}17.47- \\
23.77\end{array}$ & $\begin{array}{l}20.32- \\
26.71\end{array}$ & $\begin{array}{c}67.78- \\
85.50\end{array}$ & $\begin{array}{l}80.30- \\
98.77\end{array}$ & $\begin{array}{l}52.74- \\
76.36\end{array}$ & Badr et al. (2009) \\
\hline $\begin{array}{c}\text { Mangrove area of Peninsular } \\
\text { Malaysia }\end{array}$ & $\begin{array}{l}1.11- \\
2.00\end{array}$ & $\begin{array}{l}5.59- \\
28.7\end{array}$ & $\begin{array}{l}1.29- \\
4.89\end{array}$ & - & $\begin{array}{l}25.36- \\
172.6\end{array}$ & $\begin{array}{l}29.35- \\
130.3 \\
\end{array}$ & $\begin{array}{l}\text { Cheng and Yap } \\
\qquad(2015)\end{array}$ \\
\hline SQGs & Cd & $\mathbf{C u}$ & $\mathrm{Fe}(\%)$ & $\mathbf{N i}$ & $\mathbf{P b}$ & Zn & \\
\hline Effects range low (ERL) & 1.20 & 34.0 & - & - & 46.7 & 150 & Long et al. (1995) \\
\hline Effects range median (ERM) & 9.60 & 270 & - & - & 218 & 410 & Long et al. (1995) \\
\hline LEL & 0.6 & 16 & 2 & 16 & 31 & 120 & NYSDEC \\
\hline SEL & 9 & 110 & 4 & 50 & 110 & 270 & NYSDEC \\
\hline Treshold effect level (TEL) & 0.68 & 18.7 & - & - & 30.2 & 124 & $\begin{array}{l}\text { MacDonald et al. } \\
\text { (1996) }\end{array}$ \\
\hline Probable effect level (PEL) & 4.21 & 108.2 & - & - & 112.2 & 271 & $\begin{array}{l}\text { MacDonald et al. } \\
\text { (1996) }\end{array}$ \\
\hline RVs & Cd & $\mathbf{C u}$ & $\mathrm{Fe}(\%)$ & $\mathbf{N i}$ & $\mathbf{P b}$ & $\mathbf{Z n}$ & \\
\hline Pre-industrial reference level & 1.00 & 50.0 & - & $68.0 *$ & 70.0 & 175 & Hakanson (1980) \\
\hline Upper continental crust & 0.098 & 25.0 & - & 44.0 & 17.0 & 71.0 & $\begin{array}{c}\text { Taylor and } \\
\text { McLennan (1995) }\end{array}$ \\
\hline Upper continental crust & 0.102 & 14.3 & 3.09 & 18.6 & 17.0 & 52.0 & Wedepohl (1995) \\
\hline Upper continental crust & 0.09 & 28.0 & - & 47.0 & 17.0 & 67.0 & $\begin{array}{l}\text { Rudnick and Gao } \\
\text { (2003) }\end{array}$ \\
\hline Toxic-response factor $(T r)$ & 30.0 & 5.00 & - & 2.00 & 5.00 & 1.00 & Hakanson (1980) \\
\hline
\end{tabular}

All concentrations are presented in $\mu \mathrm{g} / \mathrm{g} \mathrm{dw}$ except for $\mathrm{Fe}$ in $\%$ and $\operatorname{Tr}$ values are unitless

The values of enrichment factor $(\mathrm{EF})$, geoaccumulation index (Igeo), contamination factor $(\mathrm{CF})$, ecological risk (ER) and potential ecological risk index (PERI) of heavy metals based on the surface sediments from all sampling sites are presented in Table 3. 
All the values of $\mathrm{EF}$ for $\mathrm{Cd}, \mathrm{Cu}, \mathrm{Ni}, \mathrm{Pb}$, and $\mathrm{Zn}$ are below 2.0, indicating 'depletion of mineral enrichment' (Sutherland, 2000; Hsu et al., 2016), except for 5 sites of Cd levels where the EF values are between 2 and 3, indicating 'moderate enrichment'. Fro Igeo, all values are below 0.0 (in negative values), indicating 'practically unpolluted' (Muller, 1969). For CF for individual metal, all values are below 1.00, indicating 'low contamination factor' (Hakanson, 1980). For ER, all values are below 40.0, indicating 'low potential ecological risk' (Hakanson, 1980). Lastly, for PERI, all values are below 150 , indicating 'low ecological risk' (Hakanson, 1980).

Table 3. Summary results (mean) enrichment factor (EF), geoaccumulation index (Igeo), contamination factor $(C F)$, ecological risk $(E R)$ and potential ecological risk index (PERI) of heavy metals based on the surface sediments from the present study

\begin{tabular}{|c|c|c|c|c|c|c|c|c|c|c|c|c|c|c|c|c|c|c|c|c|c|}
\hline \multirow[b]{2}{*}{ Sites } & & \multicolumn{4}{|c|}{$\mathbf{P l}$} & \multicolumn{4}{|c|}{$\mathrm{Cu}$} & \multicolumn{4}{|c|}{$\mathbf{Z n}$} & \multicolumn{4}{|c|}{$\mathrm{Cc}$} & \multirow{2}{*}{$\begin{array}{l}\text { Total } \\
\text { ER/ } \\
\text { PERI }\end{array}$} \\
\hline & $\mathbf{E F}$ & Igeo & CF & ER & $\mathbf{E}$ & eo & CF & $\mathbf{R}$ & EF & Igeo & CF & ER & $\mathbf{E F}$ & Igeo & CF & ER & EF & geo & CF & ER & \\
\hline 1 & 0.14 & -7.44 & 0.01 & 0.02 & 0.45 & .72 & 0.03 & 0.14 & 0.19 & -6.96 & 0.01 & 0.06 & .41 & -5.86 & 0.03 & 0.03 & 1.28 & -4.21 & 0.08 & 2.44 & .68 \\
\hline 2 & 0.11 & -7.66 & 0.01 & 1 & 0.36 & .92 & 2 & 0.12 & 0.25 & .42 & 02 & 0.09 & .22 & -6.60 & 0.02 & 0.02 & 0.17 & -6.98 & 0.01 & 0.36 & 0.60 \\
\hline 3 & 0.57 & 55 & 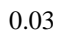 & & 6 & 22 & 2 & 0.10 & 0.21 & .01 & 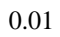 & 0.06 & 22 & 5.92 & 0.01 & 0.01 & 0.42 & -5.99 & 0.02 & 0.71 & .94 \\
\hline 4 & 0.34 & -5.93 & 0.02 & 0.05 & 0.27 & -6.30 & 0.02 & 0.09 & 0.18 & -6.87 & 0.01 & 0.06 & 0.16 & -7.06 & 0.01 & 0.01 & 0.45 & -5.56 & 0.03 & 0.96 & 1.17 \\
\hline 5 & 0.26 & -6.71 & 0.01 & 0.03 & 0.39 & 6.15 & 0.02 & 0.11 & 0.32 & -6.41 & 0.02 & 0.09 & 0.24 & -6.81 & 0.01 & 0.01 & 1.66 & -4.05 & 0.09 & 2.71 & 2.95 \\
\hline 6 & 7 & .61 & 0 & 0.03 & 0.38 & - & 2 & 0. & 0.24 & .76 & 0.01 & 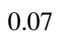 & 0.40 & -605 & 0.02 & .02 & 12 & -3.4 & 0.14 & .14 & .37 \\
\hline 7 & 0.40 & -6.02 & 0.02 & 5 & 37 & .13 & 12 & 0.11 & 0.29 & -6.50 & 0.02 & 0.08 & 20 & -7.05 & 01 & 0.01 & 1.10 & -4.5 & 0.06 & 1.91 & 2.15 \\
\hline 8 & 0.46 & -5.61 & 0.03 & 0.06 & 0.47 & -5.60 & 0.03 & 0.15 & 0.24 & -6.55 & 0.02 & 0.08 & 0.25 & -6.50 & 0.02 & 0.02 & 0.47 & -5.58 & 0.03 & 0.94 & 1.26 \\
\hline 9 & 0.50 & -5.70 & 0.03 & 0 & 0.65 & -5.31 & 0.04 & 0.19 & 0.37 & -6.12 & 0.02 & 0.11 & 0.34 & -6.27 & 0.02 & 0.02 & 1.23 & -4.40 & 0.07 & 2.14 & 2.51 \\
\hline 10 & 0.45 & -5.01 & 0.03 & & 0.41 & נד. & & 0.12 & 0.50 & |-0.50 & 0.02 & 0.09 & 0.19 & -1.00 & 0.01 & 0.01 & 2.09 & -3.58 & 0.13 & 3.76 & 4.04 \\
\hline 11 & 0.39 & -5.87 & 0.03 & 0.05 & 0.31 & $\mid-6.19$ & 0.02 & 0.10 & 0.29 & -6.29 & 0.02 & 0.10 & 0.28 & -6.32 & 0.02 & 0.02 & 0.66 & -5.10 & 0.04 & 1.31 & 1.58 \\
\hline 12 & 0.15 & -7.18 & 0.01 & 0.02 & 0.30 & -6.20 & 0.02 & 0. & 0.24 & -6.51 & 0 & 0.08 & ( & -6.77 & 0.01 & 0.01 & 1.71 & .67 & 0.12 & 3.54 & 3.76 \\
\hline 13 & 0.15 & -6.89 & 0.01 & 0.03 & 0.21 & 44 & 0.02 & 0.09 & 0.24 & -6.25 & 0.02 & 0.10 & 0.18 & 70 & 0.01 & 0.01 & 2.26 & .02 & 0.19 & 5.57 & (J.1) \\
\hline 14 & 0.23 & -6.90 & 0.01 & 0.03 & 0.17 & -7.28 & 0.01 & 0.05 & 0.39 & -6.10 & 0.02 & 0.11 & 0.46 & -5.86 & 0.03 & 0.03 & 2.22 & -3.60 & 0.12 & 3.71 & 3.92 \\
\hline 15 & 0.38 & -6.29 & 0.02 & 0.04 & 0.38 & -6.30 & 0.02 & 0.09 & 0.45 & -6.05 & 0.02 & 0.11 & 0.38 & -6.29 & 0.02 & 0.02 & 3.34 & -3.17 & 0.17 & 5.02 & 5.28 \\
\hline
\end{tabular}

\section{Conclusion}

Based on the monitoring survey of the metal concentrations in the surface sediments of Haqal coastal waters of Saudi Arabia, the values of PERI were categorised as 'low ecological risk', thus all sampling sites were unpolluted by heavy metals. Nevertheless this monitoring study showed a positive outcome of non-heavy metal pollution, future mitigation of the heavy metal pollution at the study area should be given priority by the enforcement. Further studies concerning the heavy metal assessment in this region are needed to better understand the accumulation of heavy metals and their transfer in the food web of the living organisms.

Acknowledgements. We would like to express our sincere gratitude to the farms' owners for facilitating the data collection. This study was supported by the Research Grant (S-1439-0036) provided by The Deanship of Scientific Research, University of Tabuk. This project was also partially supported by the Research Centre, College of Science, King Saud University, Riyadh. 


\section{REFERENCES}

[1] Al-Haidarey, M., Hassan, F., Al-Kubaisey, A., Douabul, A. (2010): The geoaccumulation index of some heavy metals in Al-Hawizeh Marsh, Iraq. - Journal of Chemistry 7: S157S162.

[2] Ali, B. N. M., Lin, C. Y., Cleophas, F., Abdullah, M. H., Musta, B. (2015): Assessment of heavy metals contamination in Mamut river sediments using sediment quality guidelines and geochemical indices. - Environmental Monitoring and Assessment 187: 4190.

[3] Amin, B., Ismail, A., Arshad, A., Yap, C. K., Kamarudin, M. S. (2009): Anthropogenic impacts on heavy metal concentrations in the coastal sediments of Dumai, Indonesia. Environmental Monitoring and Assessment 148: 291-305.

[4] Badr, N. B. E., El-Fiky, A. A., Mostafa, A. R., Al-Mur, B. A. (2009): Metal pollution records in core sediments of some Red Sea coastal areas, Kingdom of Saudi Arabia. Environmental Monitoring and Assessment 155: 509-526.

[5] Birch, G. F., Taylor, S. E. (2002): Assessment of possible sediment toxicity of contaminated sediments in Port Jackson, Sydney, Australia. - Hydrobiologia 472: 19-27.

[6] Birth, G. (2003): A Scheme for Assessing Human Impacts on Coastal Aquatic Environments Using Sediments. - In: Woodcofie, C. D., Furness, R. A. (eds.) Coastal GIS. Wollongong University Papers in Center for Maritime Policy, Australia.

[7] Buat-Menard, P., Chesselet, R. (1979): Variable influence of the atmospheric flux on the trace metal chemistry of oceanic suspended matter. - Earth and Planetary Science Letters 42: 399-411.

[8] CCME (2002): Canadian Sediment Quality Guidelines for the Protection of Aquatic Life. Canadian Environmental Quality Guidelines. - CCME, Winnipeg, MB, Canada.

[9] Cheng, W. H., Yap, C. K. (2015): Potential human health risks from toxic metals via mangrove snail consumption and their ecological risk assessments in the habitat sediment from Peninsular Malaysia. - Chemosphere 135: 156-165.

[10] Garcia, C. A. B., de Andrade Passos, E., Alves, J. d. P. H. (2011): Assessment of trace metals pollution in estuarine sediments using SEM-AVS and ERM-ERL predictions. Environmental Monitoring and Assessment 181: 385-397.

[11] Guo, W., Liu, X., Liu, Z., Li, G. (2010): Pollution and potential ecological risk evaluation of heavy metals in the sediments around Dongjiang Harbor, Tianjin. - Procedia Environmental Sciences 2: 729-736.

[12] Hahladakis, J. N., Vasilaki, G., Smaragdaki, E., Gidarakos, E. (2016): Application of ecological risk indicators for the assessment of Greek surficial sediments contaminated by toxic metals. - Environmental Monitoring and Assessment 188: 271.

[13] Hakanson, L. (1980): An ecological risk index for aquatic pollution control. A sedimentological approach. - Water Research 14: 975-1001.

[14] Hasan, A. B., Kabir, S., Reza, A. S., Zaman, M. N., Ahsan, A., Rashid, M. (2013): Enrichment factor and geo-accumulation index of trace metals in sediments of the ship breaking area of Sitakund Upazilla (Bhatiary-Kumira), Chittagong, Bangladesh. Journal of Geochemical Exploration 125: 130-137.

[15] Hsu, L.-C., Huang, C.-Y., Chuang, Y.-H., Chen, H.-W., Chan, Y.-T., Teah, H. Y., Chen, T.-Y., Chang, C.-F., Liu, Y.-T., Tzou, Y.-M. (2016): Accumulation of heavy metals and trace elements in fluvial sediments received effluents from traditional and semiconductor industries. - Scientific Reports 6: 34250.

[16] Hurley, R. R., Rothwell, J. J., Woodward, J. C. (2017): Metal contamination of bed sediments in the Irwell and Upper Mersey catchments, northwest England: exploring the legacy of industry and urban growth. - Journal of Soils and Sediments 17: 2648-2665.

[17] Kukrer, S., Şeker, S., Abac1, Z. T., Kutlu, B. (2014): Ecological risk assessment of heavy metals in surface sediments of northern littoral zone of Lake Çıldır, Ardahan, Turkey. Environmental Monitoring and Assessment 186: 3847-3857. 
[18] Kumwimba, M. N., Zhu, B., Wang, T., Muyembe, D. K. (2016): Distribution and risk assessment of metals and arsenic contamination in man-made ditch sediments with different land use types. - Environmental Science and Pollution Research 23: 2480824823.

[19] Long, E. R., Morgan, L. G. (1990): The Potential for Biological Effects of SedimentsSorbed Contaminants Tested in the National Status and Trends Program. - National Oceanic and Atmospheric Admininistration, Silver Spring, Maryland.

[20] Long, E. R., Macdonald, D. D., Smith, S. L., Calder, F. D. (1995): Incidence of adverse biological effects within ranges of chemical concentrations in marine and estuarine sediments. - Environmental Management 19: 81-97.

[21] Loska, K., Cebula, J., Pelczar, J., Wiechuła, D., Kwapuliński, J. (1997): Use of enrichment, and contamination factors together with geoaccumulation indexes to evaluate the content of $\mathrm{Cd}, \mathrm{Cu}$, and $\mathrm{Ni}$ in the Rybnik water reservoir in Poland. - Water, Air, and Soil Pollution 93: 347-365.

[22] Luo, W., Lu, Y., Wang, T., Hu, W., Jiao, W., Naile, J. E., Khim, J. S., Giesy, J. P. (2010): Ecological risk assessment of arsenic and metals in sediments of coastal areas of northern Bohai and Yellow Seas, China. - Ambio 39: 367-375.

[23] MacDonald, D. D. (2003): Development and applications of sediment quality criteria for managing contaminated sediment in British Columbia. - MacDonald Environmental Sciences Limited, Nanaimo, BC, Canada.

[24] MacDonald, D. D., Carr, R. S., Calder, F. D., Long, E. R., Ingersoll, C. G. (1996): Development and evaluation of sediment quality guidelines for Florida coastal waters. Ecotoxicology 5: 253-278.

[25] Madiseh, S. D., Savary, A., Parham, H., Sabzalizadeh, S. (2009): Determination of the level of contamination in Khuzestan coastal waters (Northern Persian Gulf) by using an ecological risk index. - Environmental Monitoring and Assessment 159: 521.

[26] Muller, G. (1969): Index of geoaccumulation in sediments of the Rhine River. Geojournal 2: 108-118.

[27] NYSDEC (New York State Department of Environmental Conservation) (1999): Technical Guidance for Screening Contaminated Sediments. - Division of Fish, Wildlife and Marine Resources, NYSDEC, New York.

[28] O'Connor, T. P. (2004): The sediment quality guideline, ERL, is not a chemical concentration at the threshold of sediment toxicity. - Marine Pollution Bulletin 49: 383385 .

[29] Ra, K., Kim, J.-K., Hong, S. H., Yim, U. H., Shim, W. J., Lee, S.-Y., Kim, Y.-O., Lim, J., Kim, E.-S., Kim, K.-T. (2014): Assessment of pollution and ecological risk of heavy metals in the surface sediments of Ulsan Bay, Korea. - Ocean Science Journal 49: 279289.

[30] Rudnick, R. L., Gao, S. (2003): Composition of the continental crust. - Treatise on Geochemistry 3: 659.

[31] Schiff, K., Weisberg, S. B. (1999): Iron as a reference element for determining trace metal enrichment in Southern California coastal shelf sediments. - Marine Environmental Research 48: 161-176.

[32] Sutherland, R. (2000): Bed sediment-associated trace metals in an urban stream, Oahu, Hawaii. - Environmental Geology 39: 611-627.

[33] Taylor, S. (1964): Abundance of chemical elements in the continental crust: a new table. - Geochimica et Cosmochimica Acta 28: 1273-1285.

[34] Taylor, S. R., McLennan, S. M. (1995): The geochemical evolution of the continental crust. - Reviews of Geophysics 33: 241-265.

[35] Thompson, P., Kurias, J., Mihok, S. (2005): Derivation and use of sediment quality guidelines for ecological risk assessment of metals and radionuclides released to the environment from uranium mining and milling activities in Canada. - Environmental Monitoring and Assessment 110: 71-85. 


$$
\text { - } 3075 \text { - }
$$

[36] Wang, C.-C., Niu, Z.-G., Li, Y., Sun, J., Wang, F. (2011): Study on heavy metal concentrations in river sediments through the total amount evaluation method. - Journal of Zhejiang University-Science A 12: 399-404.

[37] Wedepohl, K. H. (1995): The composition of the continental crust. - Geochimica et Cosmochimica Acta 59: 1217-1232.

[38] Wong, K. W., Yap, C. K., Nulit, R., Hamzah, M. S., Chen, S. K., Cheng, W. H., Karami, A., Al-Shami, S. A. (2017): Effects of anthropogenic activities on the heavy metal levels in the clams and sediments in a tropical river. - Environmental Science and Pollution Research 24: 116-134.

[39] Yap, C. (2010): Normalization of heavy metal concentrations of the tropical coastal surface sediments by using the metal geochemical resistant fraction. - 39: 47-50.

[40] Yap, C., Ismail, A., Tan, S., Omar, H. (2002): Concentrations of $\mathrm{Cu}$ and $\mathrm{Pb}$ in the offshore and intertidal sediments of the west coast of Peninsular Malaysia. - Environment International 28: 467-479.

[41] Zhao, S., Feng, C., Quan, W., Chen, X., Niu, J., Shen, Z. (2012): Role of living environments in the accumulation characteristics of heavy metals in fishes and crabs in the Yangtze River Estuary, China. - Marine Pollution Bulletin 64: 1163-1171. 